\title{
Penerapan Metode Profile Matching Sistem Pendukung Keputusan Demosi Karyawan (Studi Kasus: PT Nafasindo)
}

\author{
Daniel F S P Sitohang, Berto Nadeak, Putri Ramadani \\ Prodi Teknik Informatika, STMIK Budi Darma, Medan, Indonesia \\ Email: danielfriyandisitohang@gmail.com \\ Submitted 17-04-2020; Accepted 23-04-2020; Published 26-04-2020
}

\begin{abstract}
Abstrak
Salah satu upaya dalam perkembangan teknologi informasi saat ini membutuhkan informasi yang cepat dan akurat dalam implementasinya dalam penilaian kemampuan kerja karyawan yang berkinerja baik dan yag kurang baik dengan dukungan sistem pendukung keputusan menghasilkan salah satu implementasi perkembangan teknologi informasi dalam meningkatkan kualitas kerja perusahaan. dimana Proses pengambilan keputusan menentukan Demosi karyawan masih dilakukan secara manual. masih sering terdapat beberapa kesalahan seperti salah sasaran. Maka dari itu untuk melakukan penilaian dalam pengambilan keputusan memilih karyawan layak demosi berdasarkan penilaian yang dilakukan di lapangan. Maka sistem pendukung keputusan yang akan di bangun dengan sistem terkomputerisasi agar pengambilan keputusan dilakukan dengan cepat dan akurat. Untuk sistem pendukung keputusan ini menggunakan metode Profile Matching atau pencocokan prfoli demosi karyawan dengan profil karyawan yang dinilai dengan Kriteria-kriteria yang ditetapkan. Pembuatan sebuah program aplikasi harus dibuat secara matang, agar tampilannya mudah dipahami dan asalnya bermanfaat dan memuaskan bagi para pemakai. sistem yang dibangun dapat membantu PT. Nafasindo dalam menentukan demosi karyawan yang layak dan dapat mengurangi kesalahan dalam menentukan demosi karyawan.
\end{abstract}

Kata Kunci: Sistem Pendukung Keputusan, Demosi Karyawan, Profile Matching.

\begin{abstract}
One effort in the development of information technology today requires fast and accurate information in its implementation. in the assessment of the work ability of well-performing and poor employees with the support of a decision support system it produces one of the implementations of the development of information technology in improving the quality of the company's work. where the decision making process determines employee demotion is still done manually. still there are often a number of errors such as misdirection. Therefore, to make an assessment in making a decision to choose a decent demotion employee based on the assessment carried out in the field. Then the decision support system that will be built with a computerized system so that decision making is done quickly and accurately. For this decision support system, use the Profile Matching method or matching the demotion of employee demos with the profile of the employee assessed with the specified Criteria. Making an application program must be made carefully, so that it looks easy to understand and proven useful and useful for users. the system built can help PT. Nafasindo in determining the demotion of employees who are decent and can reduce errors in determining the demotion of employees.
\end{abstract}

Keywords: Decision Support System, Employee Demotion, Profile Matching.

\section{PENDAHULUAN}

Demosi karyawan adalah salah satu bagian dari pengembangan karyawan secara formal untuk menciptakan kompetisi diantara sesama karyawan guna memacu prestasi kerja para karyawan. Demosi merupakan sejenis sanksi/hukuman bagi karyawan yang prestasi kerjanya dinilai rendah oleh manajemen perusahaan. Pengertian demosi adalah suatu perpindahan dalam suatu organisasi dari satu posisi ke posisi lainnya yang melibatkan penurunan kewenangan, tanggung jawab, status, fasilitas, bahkan gaji yang diperoleh oleh karyawan tersebut dari perusahaan. Demosi terjadi dalam suatu perusahaan terutama karena pengaruh negatifnya terhadap moral karyawan yang bersangkutan dan dapat mempengaruhi prestasi dan moral karyawan lainnya di perusahaan tersebut. Penurunan kewenangan, fasilitas, status dan bahkan gaji merupakan suatu hukuman bagi karyawan tersebut agar dapat belajar memperbaiki kualitas diri dan kinerjanya sehingga diharapkan dapat menjadi lebih baik selama masa penjatuhan sanksi demosi tersebut.

Dalam melakukan proses penilaian karyawan banyak sekali kriteria yang telah ditentukan oleh perusahaan. Masingmasing perusahaan pasti memiliki kriteria-kriteria saat melakukan penilaian kinerja pada karyawannya. Banyaknya kriteria ini lah yang menyulitkan pihak manajemen untuk member bobot setiap kriteria, oleh karena itu dibutuhkan sebuah sistem pendukung keputusan. Kualitas sumber daya manusia yang tinggi dapat diperlukan untuk meningkatkan suatu perusahaan.

Pada penelitian ini akan diangkat suatu kasus yaitu mencari altenatif yang layak berdasarkan kriteria-kriteria yang telah ditentukan dengan menggunakan metode profile matching. Penelitian ini dilakukan dengan cara mencari nilai bobot untuk setiap atribut, kemdian dilakukan proses perangkingan yang akan menentukan nilai alternatif yang optimal.dalam era informasi dan teknologi yang semakin berkembang ternyata dalam proses pengolahan data karyawan untuk demosi karyawan masih sangat manual tanpa menghitung nilai-nilai kriteria, sehingga demosi karyawan tersebut sering salah sasaran. Dalam penelitian ini akan ditentukan beberapa kriteria dan data karyawan yang telah diperoleh berdasarkan hasil survei. Data tersebut akan dianalisis yang kemudian akan diolah menggunakan sistem pendukung keputusan.

Metode Profile Matching merupakan salah satu metode yang sederhana dalam sistem pendukung keputusan dengan membandingkan GAP antara nilai alternatif dan kriteria. Ada beberapa hal yang diketahui tentan Analisis GAP, salah satu diantaranya adalah tabel nilai bobot GAP. Selain itu Analisis GAP ini juga harus memahami konsep dengan range 0-5 berdasarkan prioritas setiap kriteria.

Hasil beberapa penelitian yang dilakukan menjelaskan bahwa Metode Profile Matching diharapkan dapat dikembangkan software sistem pendukung keputusan yang dapat digunakan oleh suatu perusahaan, karena perusahaan cukup 
memilih beberapa masalah yang akan menjadi alternatif pemilihan dan memberikan nilai bobot pada perbandingan alternatif dan kriterianya, adapun kriteria tersebut adalah Kriteria sikap kerja, Kriteria Kecerdasan, Kriteria Perilaku[1].

Metode dalam Sistem pendukung keputusan merupakan sebuah aplikasi yang membantu pihak manajemen dalam mengambil keputusan. dalam sistem pendukung keputusan terdapat beberapa metode sesuai dengan pemanfaatannya. dalam hal ini penulis menggunakan metode yaitu, Metode Profile Matching untuk melakukan penilaian karyawan dalam menentukan demosi karyawan pada PT. Nafasindo. Metode Profile Matching dapat membantu dalam merekomendasikan salah satu pengambilan keputusan. terutama dalam kagiatan organisasi dan manajemen sumber daya manusia, sumber daya manusia yang baik akan berdampak positif untuk perkembangan dan kemajuan organisasi atau perusahaan[1].

\section{METODE PENELITIAN}

\subsection{Sistem Pendukung Keputusan}

Sistem pedukung keputusan (Decision Support System) merupakan sistem informasi intraktif yang menyediakan informasi, pemodelan, dan pemanipulasian data. Sistem ini digunakan untuk membantu pengambilan keputusan dalam situasi yang semiterstruktur dan situasi yang tidak terstruktur, dimana tak seorang pun tahu secara pasti bagaimana keputusan seharusnya dibuat. DSS biasanya dibangun untuk medukung solusi atas suatu masalah atau untuk mengevaluasi suatu peluang. DSS seperti itu disebut aplikasi DSS. Aplikasi DSS menggunakan CBIS (Computer based information system) yang fleksibel, interaktif, dan dapat diadaptasi, yang dikembangkan untuk mendukung solusi atas masalah manajemen spesifikasi yang tidak terstruktur. Aplikasi DSS menggunakan data, memberikan antarmuka pengguna yang mudah, dan dapat menggabungkan pemikiran pengambilan keputusan[2].

\subsection{Metode Profile Matching}

Metode Profile matching secara garis besar merupakan proses membandingkan atau pencocokan profil antara kompetensi individu kedalam kompetensi tingkat variable prediktor yang ideal yang harus dipenuhi oleh subyek yang diteliti. Sehingga dapat diketahui perbedaan kompetensinya (disebut juga gap), semakin kecil gap yang dihasilkan maka bobot nilainya semakin besar yang berarti memiliki peluang lebih besar untuk karyawan menempati posisi tersebut. Dalam proses Profile Matching secara garis besar merupakan proses membandingkan antara nilai data aktual dari suatu profil yang akan dinilai dengan nilai profil yang diharapkan, sehingga dapat diketahui perbedaan kompetisinya (disebut juga Gap), semakin kecil Gap yang dihasilkan maka bobot nilainya semakin besar yang berarti memiliki peluang lebih besar untuk direkomendasikan untuk terpilih. [3]. Dalam penelitian ini Core factor diberikan sebanyak $60 \%$ dan $40 \%$ untuk secondary factor. Pemberian Rangking adalah proses perhitungan Hasil Akhir untuk menentukan karyawan yang direkomendasikan sebagai Demosi Karyawan. Berikut adalah beberapa tahapan dan perumusan perhitungan dengan metode Profile Matching:

1. Pemetaan Gap Kompetensi

GAP = Profile Karyawan - Profil Demosi Karyawan

2. Pembobotan

3. Perhitungan dan pengelompokan Core Factor dan Secondary Factor

Untuk perhitungan core factor dapat ditunjukkan pada rumus di bawah ini:

a. Core Factor (Faktor Utama)

Core Factor merupakan aspek (Kompetensi) yang paling menonjol/paling dibutuhkan oleh suatu kinerja yang diperkirakan data menghasilkan kinerja optimal. Untuk menghitung core factor digunkakan rumus:

$N C F=\frac{\sum N C(s k, k, p)}{\sum I C}$

Keterangan :

NCF : Nilai rata-rata (core factor)

$\mathrm{NC}(\boldsymbol{s} \boldsymbol{k}, \boldsymbol{k}, \boldsymbol{p}) \quad$ : Jumlah total nilai core factor

ICF : Jumlah item (core factor)

b. Secondary Factor (Faktor Pendukung) Secondary factor adalah item-item selain aspek yang ada pada core factor. untuk menghitung secondary factor digunakan rumus perhitungan secondary factor dapat ditunjukkan pada rumus di bawah ini :

$$
N S F=\frac{\sum N S(s k, k, p)}{\sum I S}
$$

Keterangan :

$\begin{array}{ll}(s k, k, p) & : \text { (Sikap Kerja, Kecerdasan, Perilaku) } \\ \text { NSF } & : \text { Nilai rata-rata (secondary factor) } \\ \text { NS } & \text { : Jumlah total nilai (Secondary factor) } \\ \text { IS } & : \text { Jumlah item (secondary factor) }\end{array}$

4. Perhitungan Nilai Total

(x) \% NCF $(s k, k, p)+(x) \% \operatorname{NSF}(s k, k, p)=N(s k, k, p)$

Keterangan : 


$\begin{array}{ll}(s k, k, p) & : \text { (Sikap Kerja, Kecerdasan, Perilaku) } \\ N C F(s k, k, p) & : \text { Nilai rata-rata (core factor) } \\ N S F(s k, k, p) & : \text { Nilai rata-rata (secondary factor) } \\ N(s k, k, p) & : \text { Nilai total dari aspek } \\ (x) \% & : \text { Nilai persen yang diinputkan }\end{array}$

5. Rangking Dari Kandidat

Ranking $=(x) \% N s k+(x) \% N k+(x) \% N p$

Keterangan:

$\begin{array}{ll}H a & : \text { Hasil Akhir } \\ N s k & : \text { Nilai Sikap Kerja } \\ N k & : \text { Nilai Kecerdasan } \\ N p & : \text { Nilai Perilaku } \\ (x) \% & \text { : Nilai Persen yang diinputkan }\end{array}$

\section{HASIL DAN PEMBAHASAN}

\subsection{Penerapan Metode Profile Matching}

1. Analisa Kebutuhan Alternatif (Kandidat)

Ada lima nama karyawan yang digunakan menjadi kandidat keputusan. Dan akan dipilih posisi yang akan dijadikan demosi terhadap karyawan. Adapun Alternatif (Kandidat) yang terdapat pada tabel dibawah ini adalah sebagai berikut:

Tabel 1. Nama Alternatif

\begin{tabular}{cccccc}
\hline No & Kode & Alternatif & SK & K & P \\
\hline 1 & K-001 & Fatma & 85 & 90 & 70 \\
2 & K-002 & Vivin & 95 & 80 & 85 \\
3 & K-003 & Abdul Rizki & 75 & 80 & 85 \\
4 & K-004 & Putri Soraya & 80 & 95 & 75 \\
5 & K-005 & Miftahul & 95 & 90 & 70 \\
\hline
\end{tabular}

2. Penentuan Nilai Gap Dan Core

Berdasarkan aspek-aspek yang telah ditentukan sebelumnya, selanjutnya adalah menentukan nilai target gab untuk masing-masing point penilaian tersebut. Berikut adalah nilai-nilai yang diharapkan seperti pada tabel dibawah ini:

Tabel 2. Nilai Gap

\begin{tabular}{llc}
\hline A. ASPEK SIKAP KERJA 45\% & Nilai Gap \\
\hline 1. & Etos kerja & 5 \\
2. $\quad$ Bertindak objektif & 5 \\
3. $\quad$ Tanggung jawab ada & 5 \\
4. $\quad$ Menunjukkan pribadi yang dewasa & 5 \\
5. Komunikasiyang baik dengan sesama & 5 \\
6. Berpola piker yang baik & 4 \\
7. Pengendalian perasaan & 4 \\
8. Kejujuran & 5 \\
B. ASPEK KECERDASAN 25\% & \\
1. Kemampuan berpikir & 4 \\
2. $\quad$ Verbalitas ide & 4 \\
3. Sistematika berpikir & 3 \\
4. Konsentrasi & 4 \\
5. Imajinatif kreatif & 4 \\
6. Penalaran & 5 \\
7. Logika & 4 \\
8. $\quad$ Fleksibilitas berpikir & 4 \\
C. ASPEK PERILAKU 30\% & \\
1. Kekuasaan (Domiance) & 5 \\
2. Pemenuhan (Compliance) & 5 \\
3. Pengaruh (Influences) & 4 \\
4. Keteguhan Hati (Steadiness) & 4 \\
5. Kesopanan & 4 \\
\hline
\end{tabular}

Selanjutnya dari masing-masing kriteria tersebut akan ditentukan bobot-bobotnya. Pada bobot tersebut terdiri dari lima kandidat yang telah memiliki data untuk dimasukkan kedalam tabel nilai untuk masing-masing aspek dan subkriteria. 
3. Pembobotan Nilai Kriteria

Ada beberapa langkah untuk melakukan perhitungan menentukan status karyawan menjadi demosi karyawan menggunkan metode profile matching yaitu:

Tabel 3. Tabel Bobot Penilaian

\begin{tabular}{cccl}
\hline No & Nilai Tertulis & Nilai Bobot & \multicolumn{1}{c}{ Bobot } \\
\hline 1 & $90-100$ & 5 & $5=$ Sangat Baik \\
2 & $70-89$ & 4 & $4=$ Baik \\
3 & $60-69$ & 3 & $3=$ Cukup Baik \\
4 & $40-59$ & 2 & $2=$ Kurang \\
5 & $<39$ & 1 & $1=$ Sangat Kurang \\
\hline
\end{tabular}

Nilai kriteria digunakan sebagai nilai bobot berdasarkan dari sub kriteria yang memiliki range 1 sampai 5 dalam penilaian setiap kriteria dengan adanya keterangan setiap nilai.

4. Penilaian Altenatif Aspek

Tahap berikutnya adalah pemilihan kandidat yang akan dilakukan penilaian. masing-masing pembobotan ini di dapat dari hasil nilai-nilai berdasarkan kriteria. kandidat yang dinilai berdasarkan point-point factor dalam kriteria seperti terlihat pada Tabel Berikut:.

Tabel 4. Nilai Alternatif Aspek Sikap Kerja

\begin{tabular}{lcccccccc}
\hline \multirow{2}{*}{ Alternatif } & \multicolumn{7}{c}{ Aspek Sikap Kerja } \\
\cline { 2 - 9 } & Sk1 & Sk2 & Sk3 & Sk4 & Sk5 & Sk6 & Sk7 & Sk8 \\
\hline Fatma & 4 & 4 & 4 & 3 & 3 & 4 & 4 & 3 \\
Vivin & 4 & 5 & 4 & 5 & 2 & 3 & 5 & 2 \\
Abdul Rizki & 4 & 5 & 3 & 2 & 2 & 4 & 5 & 3 \\
Putri Soraya & 3 & 3 & 3 & 3 & 3 & 5 & 2 & 4 \\
Miftahul & 2 & 4 & 3 & 3 & 4 & 4 & 2 & 2 \\
\hline
\end{tabular}

Tabel 5. Nilai Alternatif Aspek Kecerdasan

\begin{tabular}{lcccccccc}
\hline & \multicolumn{7}{c}{ Kriteria } \\
\cline { 2 - 9 } Alternatif & K1 & K2 & K3 & K4 & K5 & K6 & K7 & K8 \\
\hline Fatma & 2 & 2 & 4 & 5 & 1 & 5 & 5 & 2 \\
Vivin & 4 & 5 & 4 & 5 & 2 & 3 & 5 & 2 \\
Abdul Rizki & 4 & 5 & 3 & 2 & 2 & 4 & 5 & 3 \\
Putri Soraya & 3 & 3 & 3 & 3 & 3 & 5 & 2 & 1 \\
Miftahul & 2 & 4 & 3 & 3 & 4 & 4 & 2 & 1 \\
\hline
\end{tabular}

Tabel 6. Nilai Alternatif Aspek Perilaku

\begin{tabular}{lccccc}
\hline \multirow{2}{*}{ Alternatif } & \multicolumn{5}{c}{ Kriteria } \\
\cline { 2 - 6 } & $\mathbf{P ( 1 )}$ & $\mathbf{P}(\mathbf{2})$ & $\mathbf{P ( 3 )}$ & $\mathbf{P ( 4 )}$ & $\mathbf{P ( 5 )}$ \\
\hline Fatma & 2 & 2 & 4 & 5 & 1 \\
Vivin & 4 & 5 & 4 & 5 & 2 \\
Abdul & 4 & 5 & 3 & 2 & 2 \\
Putri & 3 & 3 & 3 & 3 & 3 \\
Miftahul & 2 & 4 & 3 & 3 & 4 \\
\hline
\end{tabular}

5. Pemetaan Gap Kompentensi

Gap yang dimaksud pada aspek ini, melakukan perhitungan gap antara profil karyawan dikurang dengan Profil nilai demosi. Adapun perhitungan bobot profil demosi untuk masing-masing aspek ditunjukkan pada Tabel berikut dengan menggunakan Rumus :

\section{Gap = Profil Karyawan - Profil Demosi}

a. Perhitungan Pemetaan Gap Sikap Kerja

Adapun perhitungan gap Aspek Sikap Kerja terdapat pada Tabel 7.

Tabel 7. Tabel Nilai Gap Aspek Sikap Kerja

\begin{tabular}{llllllllll}
\hline \multirow{2}{*}{ No } & \multirow{2}{*}{ Alternatif } & \multicolumn{7}{c}{ Variabel } \\
\cline { 3 - 9 } & & $\operatorname{Sk}(1)$ & $\operatorname{Sk}(2)$ & $\operatorname{Sk}(3)$ & $\operatorname{Sk}(4)$ & $\operatorname{Sk}(5)$ & $\operatorname{Sk}(6)$ & $\operatorname{Sk}(7)$ & $\operatorname{Sk}(8)$ \\
\hline 1 & Fatma & 4 & 4 & 4 & 3 & 3 & 4 & 4 & 3 \\
2 & Vivin & 4 & 5 & 4 & 5 & 2 & 3 & 5 & 2 \\
3 & Abdul Rizki & 4 & 5 & 3 & 2 & 2 & 4 & 5 & 3 \\
4 & Putri Soraya & 3 & 3 & 3 & 3 & 3 & 5 & 2 & 4
\end{tabular}




\begin{tabular}{lllllllllll}
5 & Miftahul & 2 & 4 & 3 & 3 & 4 & 4 & 2 & 2 & \\
Profil Demosi & $\mathbf{5}$ & $\mathbf{5}$ & $\mathbf{5}$ & $\mathbf{5}$ & $\mathbf{5}$ & $\mathbf{4}$ & $\mathbf{4}$ & $\mathbf{5}$ & \\
1 & Fatma & -1 & -1 & -1 & -2 & -2 & 0 & 0 & -2 & \\
2 & Vivin & -1 & 0 & -1 & 0 & -3 & -1 & 1 & -3 & \\
3 & Abdul Rizki & -1 & 0 & -2 & -3 & -3 & 0 & 1 & -2 & Gap \\
4 & Putri Soraya & -2 & -2 & -2 & -2 & -2 & 1 & -2 & -1 & \\
5 & Miftahul & -3 & -1 & -2 & -2 & -1 & 0 & -2 & -3 & \\
\hline
\end{tabular}

Tabel 8. Tabel Nilai Gap Aspek Kecerdasan

\begin{tabular}{clcccccccc}
\hline \multirow{2}{*}{ No } & \multirow{2}{*}{ Alternatif } & \multicolumn{10}{c}{ Kriteria } \\
\cline { 2 - 9 } & & $\mathrm{k} 1$ & $\mathrm{k} 2$ & $\mathrm{k} 3$ & $\mathrm{~K} 4$ & $\mathrm{~K} 5$ & $\mathrm{~K} 6$ & $\mathrm{~K} 7$ & $\mathrm{~K} 8$ \\
\hline 1 & Fatma & 2 & 2 & 4 & 5 & 1 & 5 & 5 & 2 \\
2 & Vivin & 4 & 5 & 4 & 5 & 2 & 3 & 5 & 2 \\
3 & Abdul & 4 & 5 & 3 & 2 & 2 & 4 & 5 & 3 \\
4 & Putri S & 3 & 3 & 3 & 3 & 3 & 5 & 2 & 1 \\
5 & Miftahul & 2 & 4 & 3 & 3 & 4 & 4 & 2 & 1 \\
Profil Demosi & $\mathbf{4}$ & $\mathbf{4}$ & $\mathbf{3}$ & $\mathbf{4}$ & $\mathbf{4}$ & $\mathbf{5}$ & $\mathbf{4}$ & $\mathbf{4}$ \\
1 & Fatma & -2 & -2 & 1 & 1 & -3 & 0 & 1 & -2 \\
2 & Vivin & 0 & 1 & 1 & 1 & -2 & -2 & 1 & -2 \\
3 & Abdul & 0 & 1 & 0 & -2 & -2 & -1 & 1 & -1 \\
4 & Putri S & -1 & -1 & 0 & -1 & -1 & 0 & -2 & -3 \\
5 & Miftahul & -2 & 0 & 0 & -1 & 0 & -1 & -2 & -3 \\
\hline
\end{tabular}

Tabel 9. Tabel Nilai Gap Aspek Perilaku

\begin{tabular}{clrrrrrl}
\hline \multirow{2}{*}{ No } & \multirow{2}{*}{ Alternatif } & \multicolumn{6}{c}{ Kriteria } \\
\cline { 2 - 6 } & & $\mathbf{1}$ & $\mathbf{2}$ & $\mathbf{3}$ & $\mathbf{4}$ & $\mathbf{5}$ \\
\hline 1 & Fatma & 2 & 2 & 4 & 5 & 1 \\
2 & Vivin & 4 & 5 & 4 & 5 & 2 \\
3 & Abdul & 4 & 5 & 3 & 2 & 2 \\
4 & Putri S & 3 & 3 & 3 & 3 & 3 & \\
5 & Miftahul & 2 & 4 & 3 & 3 & 4 & \\
Profil Demosi & $\mathbf{5}$ & $\mathbf{5}$ & $\mathbf{4}$ & $\mathbf{4}$ & $\mathbf{4}$ & \\
1 & Fatma & -3 & -3 & 0 & 1 & -3 & \\
2 & Vivin & -1 & 0 & 0 & 1 & -2 & \\
3 & Abdul & -1 & 0 & -1 & -2 & -2 & Gap \\
4 & Putri S & -2 & -2 & -1 & -1 & -1 & \\
5 & Miftahul & -3 & -1 & -1 & -1 & 0 & \\
\hline
\end{tabular}

6. Pembobotan Nilai GAP

Setelah diperoleh nilai Gap dari masing-masing Alternatif, maka setiap alternatif profil diberi bobot nilai sesuai ketentuan Tabel pada Tabel Nilai Gap yang akan digunakan, untuk lebih jelasnya dapat dilihat pada tabel di bawah sebagai berikut:

Tabel 10. Bobot Nilai GAP

\begin{tabular}{llll}
\hline No & Selisih & Bobot Nilai & Keterangan \\
\hline 1 & 0 & 5 & Tidak ada selisih (Kopetensi sesuai dengan yang dibutuhkan) \\
2 & 1 & 4,5 & Kompetensi individu kelebihan 1 tingkat/level \\
3 & -1 & 4 & Kompetensi individu kekurangan 1 tingkat /level \\
4 & 2 & 3,5 & Kompetensi individu kelebihan 2 tingkat /level \\
5 & -2 & 3 & Kompetensi individu kekurangan 2 tingkat /level \\
6 & 3 & 2,5 & Kompetensi individu kelebihan 3 tingkat /level \\
7 & -3 & 2 & Kompetensi individu kekurangan 3 tingkat /level \\
8 & 4 & 1,5 & Kompetensi individu kelebihan 4 tingkat /level \\
9 & -4 & 1 & Kompetensi individu kekurangan 4 tingkat /level \\
\hline
\end{tabular}

Setelah memperoleh nilai gap dari masing-masing alternatif, maka selanjutnya untuk pemberian nilai bobot setiap kriteria berdasarkan selisih yang didapat sesuai ketentuan Tabel Bobot Nilai Gap. lebih jelas bisa di lihat pada tabel-tabel di bawah ini:

Tabel 11. Nilai Bobot Aspek Sikap Kerja

\begin{tabular}{lllllllll}
\hline \multirow{2}{*}{ No } & \multirow{2}{*}{ Alternatif } & \multicolumn{7}{c}{ Variabel } \\
\cline { 2 - 8 } & Sk1 & Sk2 & Sk3 & Sk4 & Sk5 & Sk6 & Sk7 & Sk8 \\
\hline
\end{tabular}




\begin{tabular}{lllllllllll}
\hline 1 & Fatma & -1 & -1 & -1 & -2 & -2 & 0 & 0 & -2 & \\
2 & Vivin & -1 & 0 & -1 & 0 & -3 & -1 & 1 & -3 & \\
3 & Abdul & -1 & 0 & -2 & -3 & -3 & 0 & 1 & -2 & \\
4 & Putri S & -2 & -2 & -2 & -2 & -2 & 1 & -2 & -1 & \\
5 & Miftahul & -3 & -1 & -2 & -2 & -1 & 0 & -2 & -3 & \\
\multicolumn{7}{c}{ Hasil Bobot Nilai Gap } & & & & \\
1 & Fatma & 4 & 4 & 4 & 3 & 3 & 5 & 5 & 3 & \\
2 & Vivin & 4 & 5 & 4 & 5 & 2 & 4 & 4.5 & 2 & \\
3 & Abdul & 4 & 5 & 3 & 2 & 2 & 5 & 4.5 & 3 & Gap \\
4 & Putri S & 3 & 3 & 3 & 3 & 3 & 4.5 & 3 & 4 & \\
5 & Miftahul & 2 & 4 & 3 & 3 & 4 & 5 & 3 & 2 & \\
\hline
\end{tabular}

Tabel 12. Nilai Bobot Aspek Kecerdasan

\begin{tabular}{|c|c|c|c|c|c|c|c|c|c|c|}
\hline \multirow{2}{*}{ No } & \multirow{2}{*}{ Alternatif } & \multicolumn{8}{|c|}{ Kriteria } & \\
\hline & & $\mathrm{k} 1$ & $\mathrm{k} 2$ & $\mathrm{k} 3$ & K4 & K5 & K6 & K7 & K8 & \\
\hline 1 & Fatma & -2 & -2 & 1 & 1 & -3 & 0 & 1 & -2 & \\
\hline 2 & Vivin & 0 & 1 & 1 & 1 & -2 & -2 & 1 & -2 & \\
\hline 3 & Abdul & 0 & 1 & 0 & -2 & -2 & -1 & 1 & -1 & \\
\hline 4 & Putri S & -1 & -1 & 0 & -1 & -1 & 0 & -2 & -3 & \\
\hline 5 & Miftahul & -2 & 0 & 0 & -1 & 0 & -1 & -2 & -3 & \\
\hline \multicolumn{11}{|c|}{ Hasil Bobot Nilai Gap } \\
\hline 1 & Fatma & 3 & 3 & 4.5 & 4.5 & 2 & 5 & 4.5 & 3 & \multirow{5}{*}{ Gap } \\
\hline 2 & Vivin & 5 & 4.5 & 4.5 & 4.5 & 3 & 3 & 4.5 & 3 & \\
\hline 3 & Abdul & 5 & 4.5 & 5 & 3 & 3 & 4 & 4.5 & 4 & \\
\hline 4 & Putri S & 4 & 4 & 5 & 4 & 4 & 5 & 3 & 2 & \\
\hline 5 & Miftahu & 3 & 5 & 5 & 4 & 5 & 4 & 3 & 2 & \\
\hline
\end{tabular}

Tabel 13. Nilai Bobot Aspek Perilaku

\begin{tabular}{llrrrrr}
\hline \multirow{2}{*}{ No } & \multirow{2}{*}{ Alternatif } & $\mathbf{1}$ & $\mathbf{2}$ & $\mathbf{3}$ & $\mathbf{4}$ & $\mathbf{5}$ \\
\hline 1 & Fatma & -3 & -3 & 0 & 1 & -3 \\
2 & Vivin & -1 & 0 & 0 & 1 & -2 \\
3 & Abdul & -1 & 0 & -1 & -2 & -2 \\
4 & Putri S & -2 & -2 & -1 & -1 & -1 \\
5 & Miftahul & -3 & -1 & -1 & -1 & 0 \\
& & Hasil Bobot Nilai Gap & & & \\
1 & Fatma & 2 & 2 & 5 & 4.5 & 2 \\
2 & Vivin & 4 & 5 & 5 & 4.5 & 3 \\
3 & Abdul & 4 & 5 & 4 & 3 & 3 \\
4 & Putri S & 3 & 3 & 4 & 4 & 4 \\
5 & Miftahul & 2 & 4 & 4 & 4 & 5 \\
\hline
\end{tabular}

7. Perhitungan Core Factor Dan Secondary Factor

Perhitungan dan Pengelompokan Core Factor dan Secondary Factor Setelah menentukan bobot nilai gap untuk ketiga aspek, yaitu aspek sikap kerja, kecerdasan, dan Perilaku dengan cara yang sama. Kemudian setiap aspek dikelompokkan menjadi 2 kelompok, yaitu: Core Factor dan Secondary Factor. Perhitungan Core Factor ditunjukkan pada persamaan (1) di bawah ini dengan Rumus:

$N C F=\frac{\sum \boldsymbol{N} C(\boldsymbol{s k}, \boldsymbol{k}, \boldsymbol{p})}{\sum I C}$

Sementara itu untuk perhitungan secondary factor dapat ditunjukkan pada rumus di bawah ini :

$N S F=\frac{\sum N S(\boldsymbol{s} \boldsymbol{k}, \boldsymbol{k}, p)}{\sum I S}$

Adapun hasil setiap perhitungan dan pengelompokan Core Factor dan Secondary Factor pada setiap aspek sebagai berikut:

Tabel 14. Tabel Hasil CF dan SF Aspek Sikap Kerja

\begin{tabular}{lllllllllll}
\hline Alternatif & $\mathbf{1}$ & $\mathbf{2}$ & $\mathbf{3}$ & $\mathbf{4}$ & $\mathbf{5}$ & $\mathbf{6}$ & $\mathbf{7}$ & $\mathbf{8}$ & $\boldsymbol{C F}$ & $\boldsymbol{S} \boldsymbol{F}$ \\
\hline Fatma & 4 & 4 & 4 & 3 & 3 & 5 & 5 & 3 & 3.6 & 4.3 \\
\hline
\end{tabular}




\begin{tabular}{lcccccccccc}
\hline Vivin & 4 & 5 & 4 & 5 & 2 & 4 & 4.5 & 2 & 4.0 & 3.5 \\
Abdul & 4 & 5 & 3 & 2 & 2 & 5 & 4.5 & 3 & 3.2 & 4.2 \\
Putri S & 3 & 3 & 3 & 3 & 3 & 4.5 & 3 & 4 & 3.0 & 3.8 \\
Miftahul & 2 & 4 & 3 & 3 & 4 & 5 & 3 & 2 & 3.2 & 3.3 \\
\hline
\end{tabular}

Tabel 15. Tabel Hasil CF dan SF Aspek Kecerdasan

\begin{tabular}{lcccccccccc}
\hline Alternatif & $\mathbf{1}$ & $\mathbf{2}$ & $\mathbf{3}$ & $\mathbf{4}$ & $\mathbf{5}$ & $\mathbf{6}$ & $\mathbf{7}$ & $\mathbf{8}$ & $\boldsymbol{C F}$ & $\boldsymbol{S F}$ \\
\hline Fatma & 3 & 3 & 4.5 & 4.5 & 2 & 5 & 4.5 & 3 & 3.8 & 3.6 \\
Vivin & 5 & 4.5 & 4.5 & 4.5 & 3 & 3 & 4.5 & 3 & 4.6 & 3.4 \\
Abdul & 5 & 4.5 & 5 & 3 & 3 & 4 & 4.5 & 4 & 4.4 & 3.9 \\
Putri S & 4 & 4 & 5 & 4 & 4 & 5 & 3 & 2 & 4.3 & 3.5 \\
Miftahul & 3 & 5 & 5 & 4 & 5 & 4 & 3 & 2 & 4.3 & 3.5 \\
\hline
\end{tabular}

Tabel 16. Tabel Hasil CF dan SF Aspek Perilaku

\begin{tabular}{lccccccc}
\hline Alternatif & P1 & P2 & P3 & P4 & P5 & $\boldsymbol{C F}$ & SF \\
\hline Fatma & 2 & 2 & 5 & 4.5 & 2 & 3.0 & 3.3 \\
Vivin & 4 & 5 & 5 & 4.5 & 3 & 4.7 & 3.8 \\
Abdul & 4 & 5 & 4 & 3 & 3 & 4.3 & 3.0 \\
Putri S & 3 & 3 & 4 & 4 & 4 & 3.3 & 4.0 \\
Miftahul & 2 & 4 & 4 & 4 & 5 & 3.3 & 4.5 \\
\hline
\end{tabular}

8. Perhitungan Nilai Total

Dari hasil perhitungan setiap aspek di atas, berikutnya dihitung nilai total berdasarkan persentase dari core factor dan secondary factor yang diperkirakan berpengaruh terhadap kinerja tiap-tiap profil. Berikut perhitungan dapat ditunjukkan pada rumus di bawah ini:

$(x) \% N C F(s k, k, p)+(x) \% N S F(s k, k, p)=N(s k, k, p)$

Untuk lebih jelasnya penghitungan nilai total terlebih dahulu menentukan nilai persen yang diinputkan yaitu core factor $60 \%$ dan secondary factor $40 \%$ pada Aspek Sikap Kerja, core factor 50\% dan secondary factor 50\% pada Aspek Kecerdasan, core factor $70 \%$ dan secondary factor $30 \%$ pada aspek Perilaku . Kemudian nilai core factor dan secondary factor ini dijumlahkan sesuai rumus dan hasilnya dapat dilihat pada perhitungan Sikap Kerja, Kecerdasan, dan perilaku.

Tabel 17. Tabel Nilai Total Gap Sikap Kerja

\begin{tabular}{clccc}
\hline \multirow{2}{*}{ No } & \multirow{2}{*}{ Alternatif } & \multicolumn{2}{c}{ Aspek Kecerdasan } & \multirow{2}{*}{ NSk } \\
\cline { 3 - 4 } & & Core Factor & Secondary Factor & \\
\hline 1 & Fatma & 3.6 & 4.3 & 3.88 \\
2 & Vivin & 4 & 3.5 & 3.80 \\
3 & Abdul & 3.2 & 4.2 & 3.60 \\
4 & Putri S & 5 & 3.8 & 4.52 \\
5 & Miftahul & 3.2 & 3.3 & 3.24 \\
\hline
\end{tabular}

Tabel 18. Tabel Nilai Total Gap Kecerdasan

\begin{tabular}{|c|c|c|c|c|}
\hline \multirow{2}{*}{ No } & \multirow{2}{*}{ Alternatif } & \multicolumn{2}{|c|}{ Aspek Sikap Kerja } & \multirow{2}{*}{ Nk } \\
\hline & & Core Factor & Secondary Factor & \\
\hline 1 & Fatma & 3.8 & 3.6 & 3.70 \\
\hline 2 & Vivin & 4.6 & 3.4 & 4.00 \\
\hline 3 & Abdul & 4.6 & 3.9 & 4.15 \\
\hline 4 & Putri S & 4.3 & 3.5 & 3.90 \\
\hline 5 & Miftahul & 4.3 & 3.5 & 3.90 \\
\hline
\end{tabular}

Tabel 19. Tabel Nilai Total Gap Aspek Perilaku

\begin{tabular}{|c|c|c|c|c|}
\hline \multirow{2}{*}{ No } & \multirow{2}{*}{ Alternatif } & \multicolumn{2}{|c|}{ Aspek Perilaku } & \multirow{2}{*}{$\mathbf{N P}$} \\
\hline & & Core Factor & Secondary Factor & \\
\hline 1 & Fatma & 3 & 3.3 & 3.09 \\
\hline 2 & Vivin & 4.7 & 3.8 & 4.43 \\
\hline 3 & Abdul & 4.3 & 3.0 & 3.91 \\
\hline 4 & Putri S & 3.3 & 4.0 & 3.51 \\
\hline 5 & Miftahul & 3.3 & 4.5 & 3.66 \\
\hline
\end{tabular}

9. Perhitungan Penentuan Ranking 


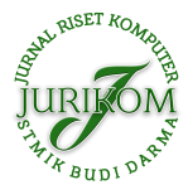

JURIKOM (Jurnal Riset Komputer), Vol. 7 No. 2, April 2020 e-ISSN 2715-7393 (Media Online), p-ISSN 2407-389X (Media Cetak) DOI 10.30865/jurikom.v7i2.211

Hal 290-300

Hasil akhir dari proses profile matching adalah ranking dari kandidat yang dijadikan untuk demosi karyawan. Perangkingan ditentukan dari nilai total penilaian, dimana alternatif dengan nilai total terkecil dipilih sebagain hasil akhirnya. Untuk penentuan rangking dapat dijadikan rumus sebagai berikut:

Rangking $=(45 \% \times N s k)+(25 \% \times N k)+(30 \% \times N p)$

Berdasarkan hasil perhitungan dengan metode Profile Matching maka hasil akhir proses Profile Matching pada Tabel 20. di bawah ini:

Tabel 20. Tabel Hasil Akhir Proses Profile Matching

\begin{tabular}{cclcccc}
\hline No & Kode & Alternatif & Nsk & Nk & Np & Nilai Akhir \\
\hline 1 & K001 & Fatma & 3.88 & 3.70 & 3.09 & 3.60 \\
2 & K002 & Vivin & 3.8 & 4.00 & 4.43 & 4.04 \\
3 & K003 & Abdul & 3.6 & 4.15 & 3.91 & 3.83 \\
4 & K004 & Putri S & 3.32 & 3.90 & 3.51 & 3.52 \\
5 & K005 & Miftahul & 3.24 & 3.90 & 3.66 & 3.53 \\
\hline
\end{tabular}

Berdasarkan hasil perhitungan dengan metode profile matching dan berdasarkan data yang ada serta kriteria yang telah ditentukan maka diperoleh hasil bahwa yang lebih layak untuk mendapatkan Demosi Karyawan dengan jumlah nilai antara Fatma, Vivin, Abdul, Putri dan Miftahul. Dengan hasil nilai terendah dari setiap penilaian adalah, Diana, sehingga kandidat (Kode_Karyawan) yang terpilih Yaitu, PK-004: Miftahul dengan hasil nilai akhir= 3.53.

\subsection{Implementasi}

Pada penelitian ini, sistem dibangun menggunakan Pemograman Visual Basic.Net 2008, berikut merupakan implementasi sistem dari langkah pertama hingga penentuan solusi.

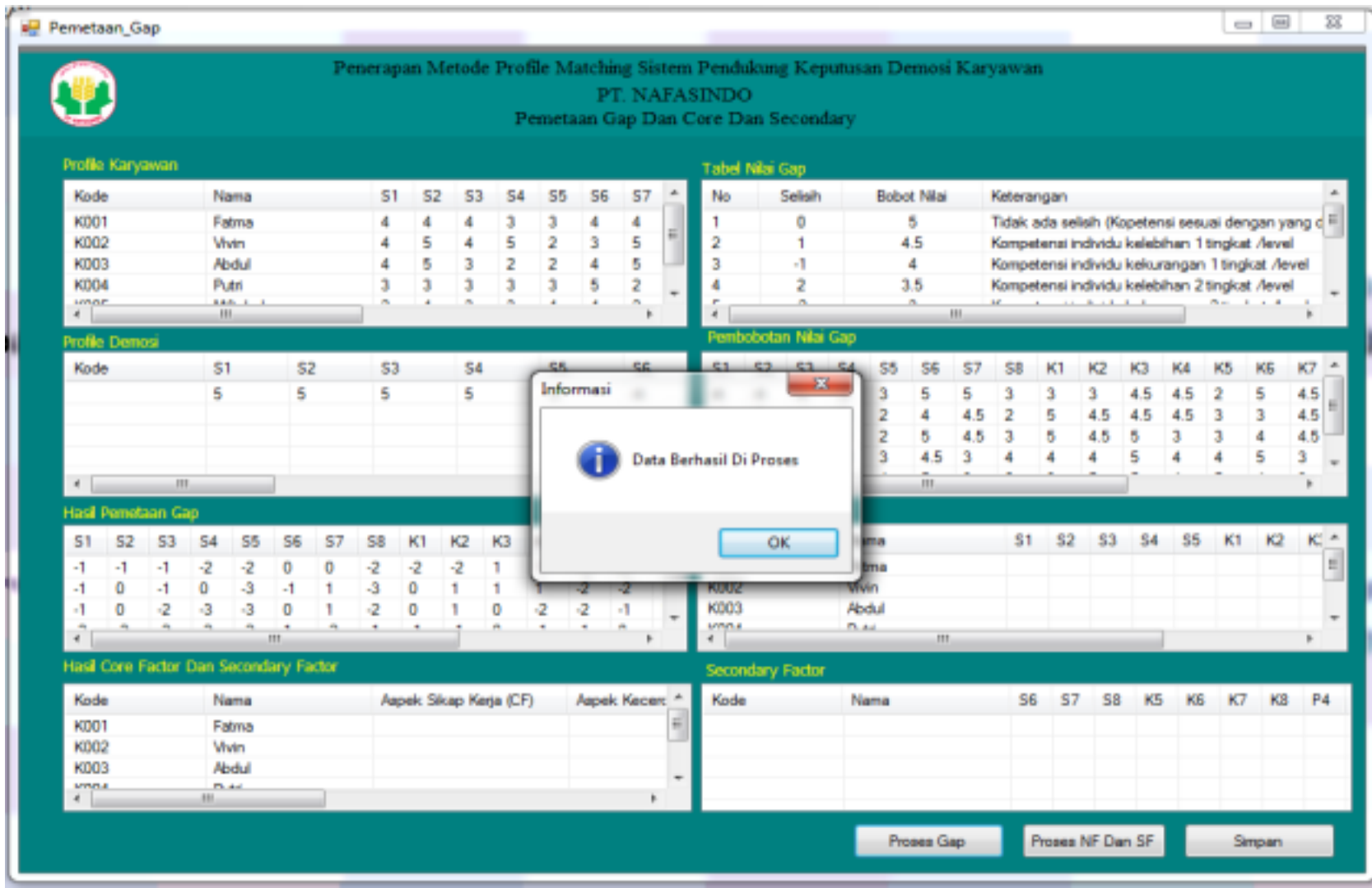

Gambar 1. Tampilan Input Nilai Karyawan.

1. Tampilan Perhitungan Gap dan Core

Form ini digunakan untuk menampilkan hasil nilai dari pemetaan gap profil demosi dan profil karyawan. Pemetaan gap yang disertai dengan hasil nilai gap yang di akan dibagi dua menjadi core factor dan secondary factor, hingga hasil dari kedua core factor dan secondary factor masuk ke penilaian. yang ada pada program dapat di lihat pada gambar 2 : 


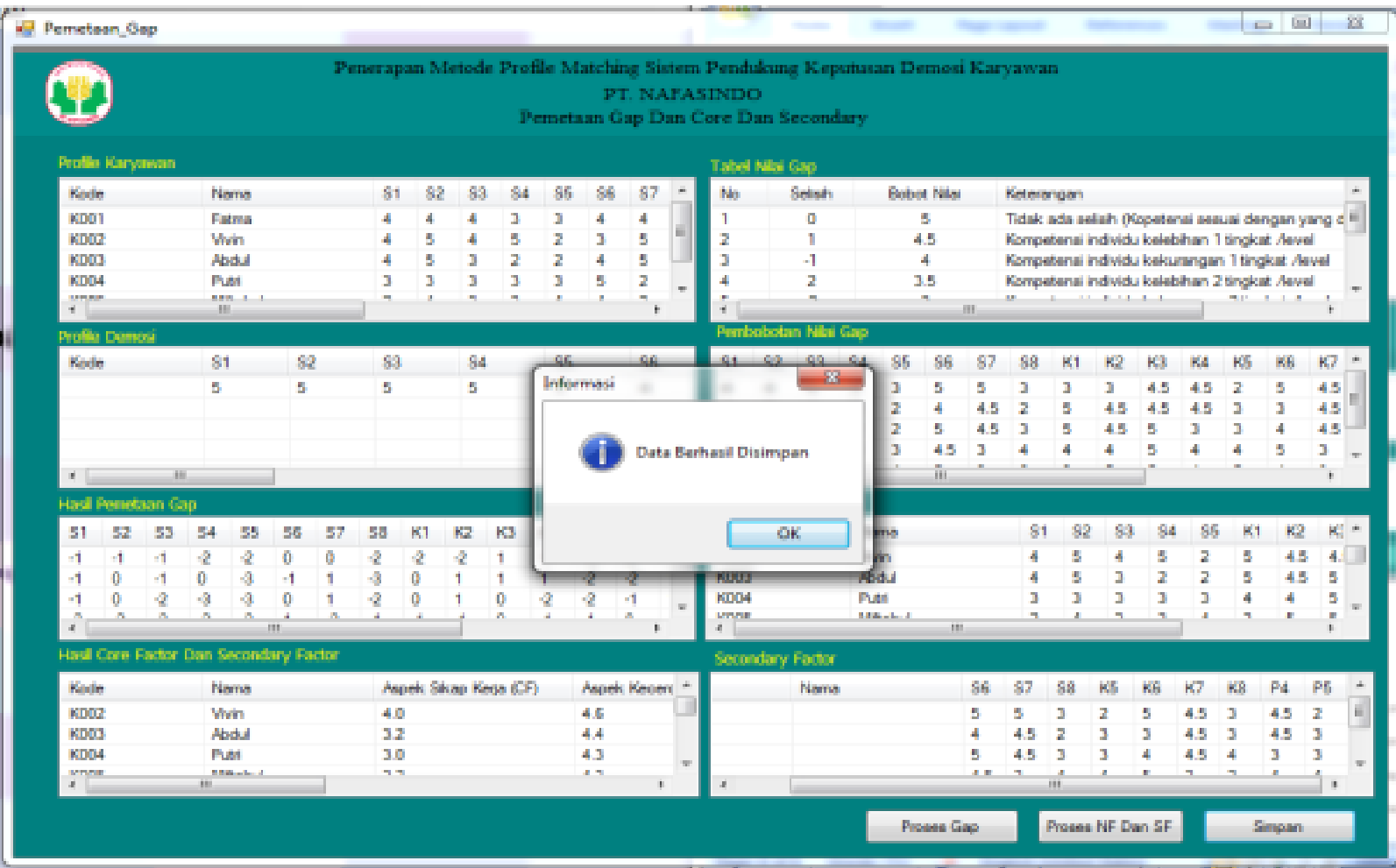

Gambar 2. Tampilan Proses Pemetaan Gap.

2. Tampilan Perhitungan Core Factor Dan Secondary Factor

Form ini digunakan untuk menampilkan hasil nilai dari pemetaan Core Factor Dan Secondary Factor. Pemetaan gap yang disertai dengan hasil nilai gap yang dibagi dua menjadi core factor dan secondary factor, hingga hasil dari kedua core factor dan secondary factor masuk ke penilaian. Seperti yang ada pada program. dapat di lihat pada gambar 3 :

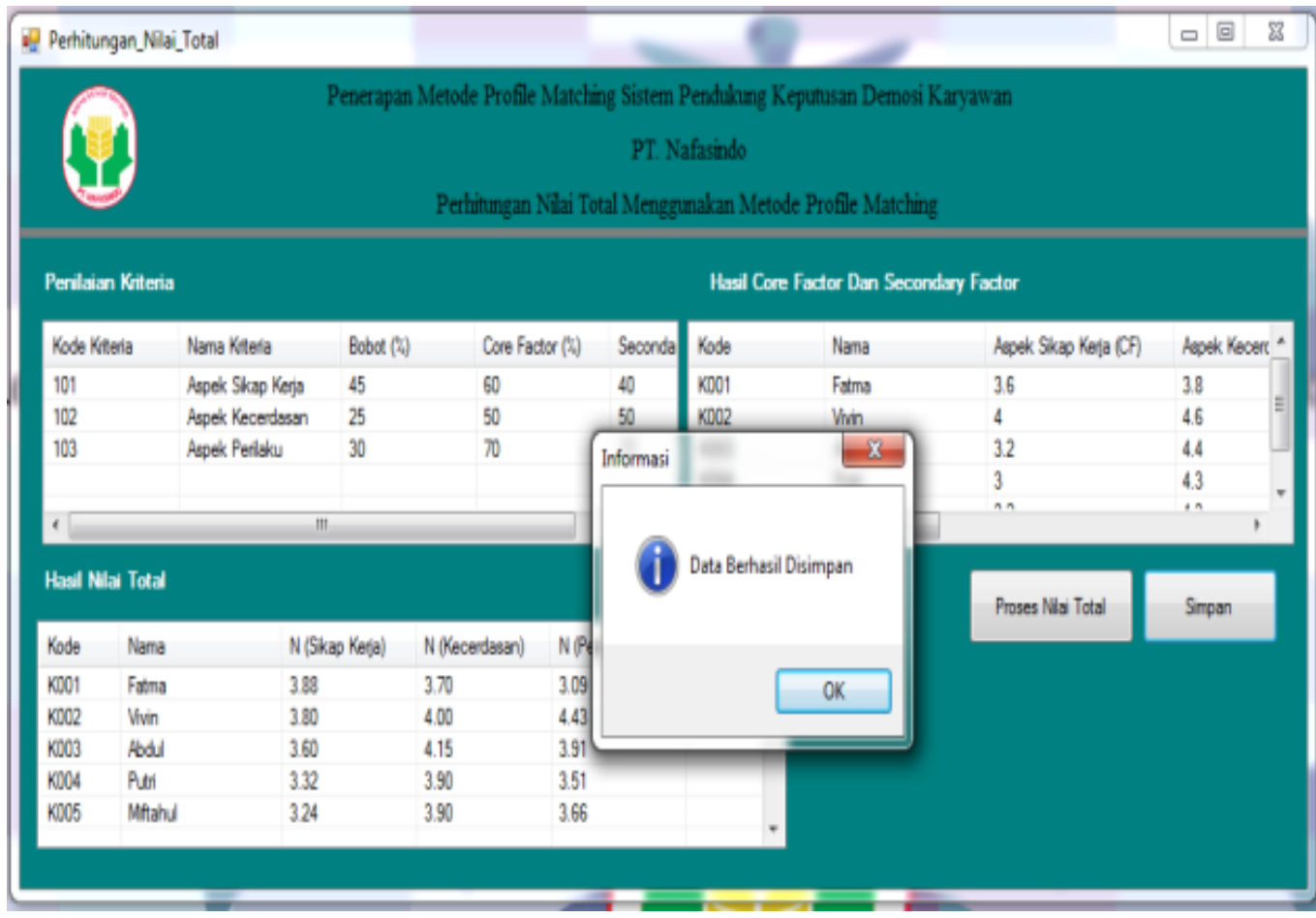

Gambar 3. Tampilan Proses NF Dan SF.

3. Tampilan Form Penentuan Nilai Total

Form ini digunakan untuk menampilkan hasil nilai total dari penilaian kriteria pada core factor dan secondary factor. yang ada pada program dapat di lihat pada gambar 4 berikut ini : 


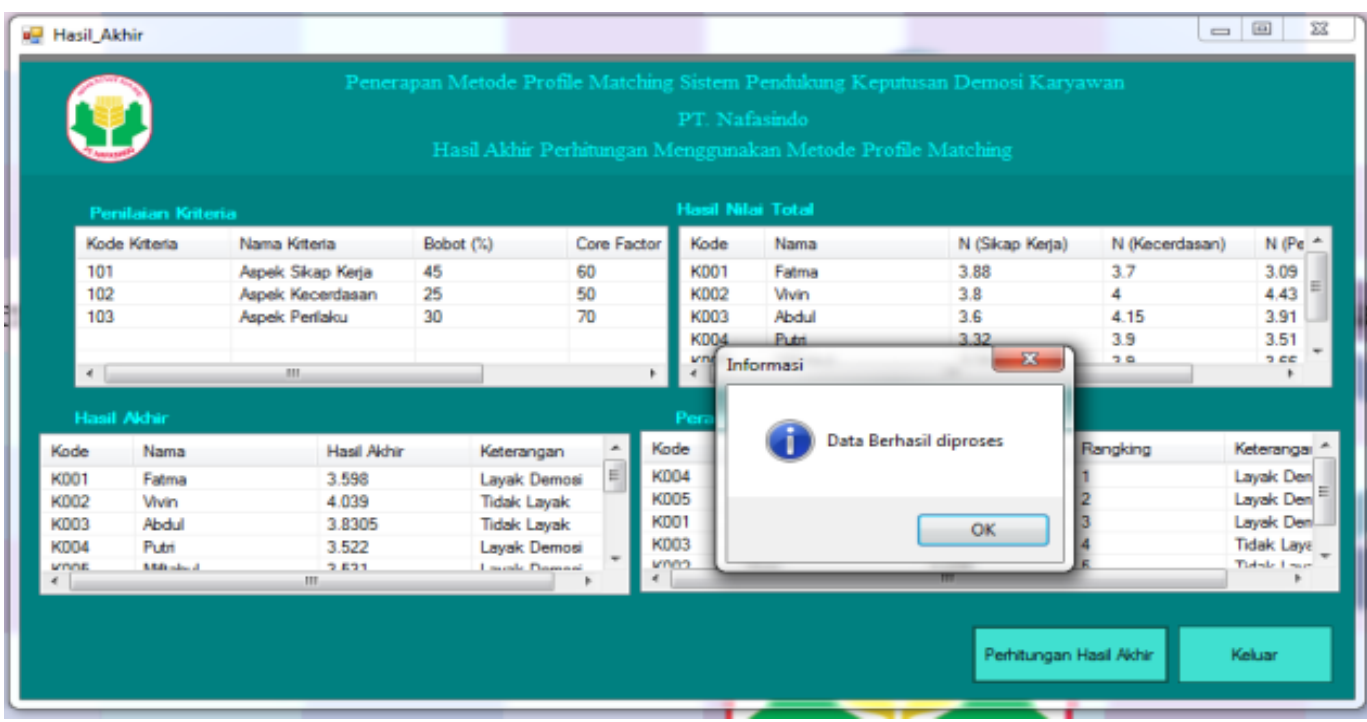

Gambar 4. Tampilan Hitung Nilai Total

4. Tampilan Nilai Hasil Akhir

Pada tampilan nilai hasil akhir ini menampilkan hasil akhir perhitungan pada setiap kriteria yang telah dinilai dan mendapatkan nilai hasil.

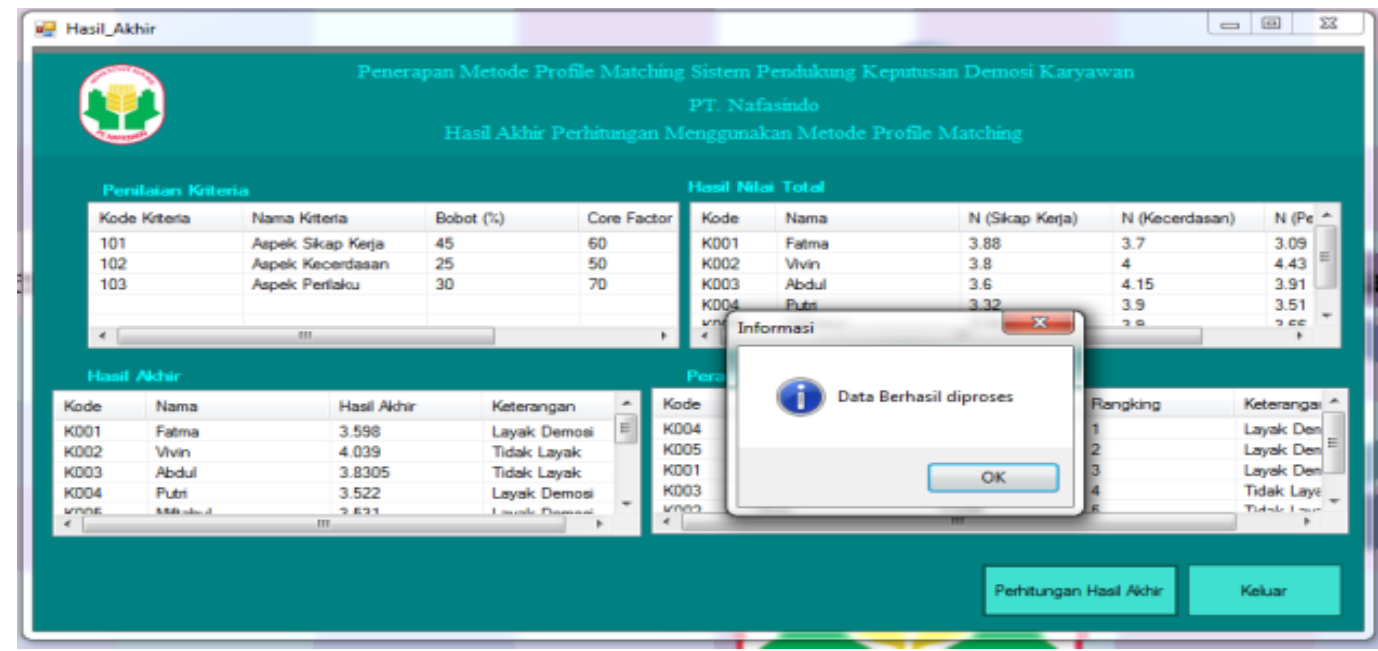

Gambar 5. Tampilan Nilai Hasil Akhir.

5. Laporan Hasil Output

Form hasil merupakan form untuk menampilkan hasil laporan. Tampilan laporan Demosi karyawan merupakan halaman untuk menampilkan data karyawan yang layak mendapat Demosi. Berikut adalah gambar hasil implementasi dari rancangan laporan Demosi Karyawan dapat dilihat pada Gambar 6 di bawah ini:

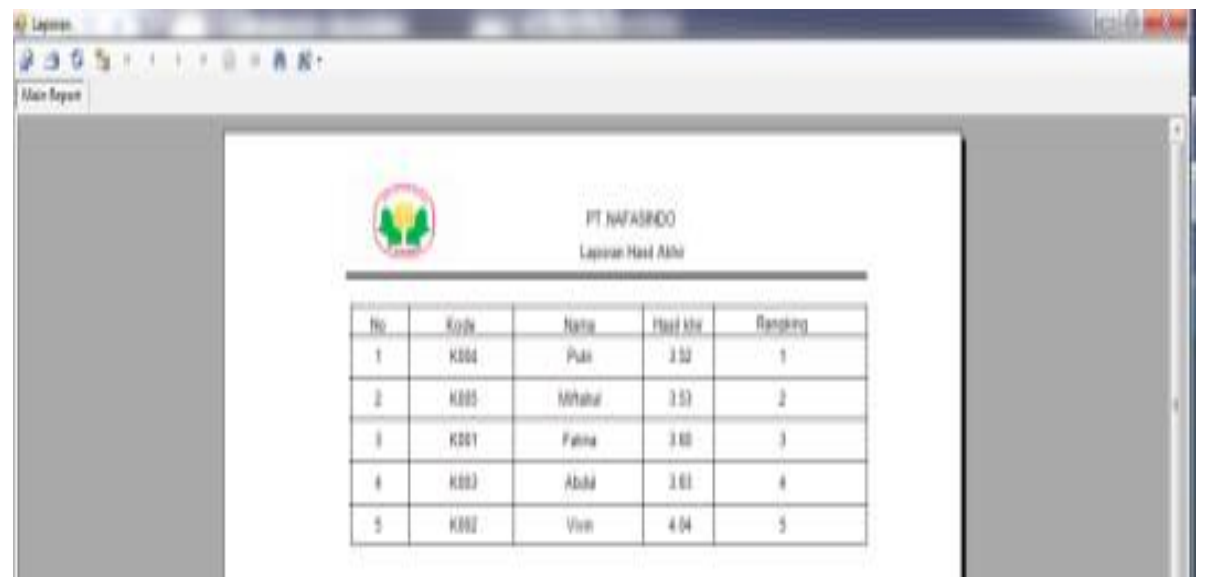

Gambar 6. Tampilan Laporan Hasil 


\section{KESIMPULAN}

Adapun kesimpulan penelitian ini yang berjudul Sistem Pendukung Keputusan Demosi karyawan pada PT. Nafasindo adalah sebagai berikut :

1. Aplikasi ini dirancang sesuai dengan hasil riset dan ketentuan dari PT. Nafasindo yang akhirnya menghasilkan suatu aplikasi berbasis dekstop programming guna untuk mempermudah penilaian untuk Demosi Karyawan.

2. Aplikasi ini menggunakan metode Profile Matching yang sangat memberi kemudahan bagi pihak Perusahaan PT. Nafasindo dalam menentukan demosi karyawan melalui beberapa pengujian seperti, membandingkan hasil perhitungan manual dengan perhitungan aplikasi yang telah dibuat untuk mengetahui keakuratan dan kemudahan dalam proses tersebut.

3. Penentuan kriteria untuk demosi karyawan dilakukan dengan memberikan 3 Aspek kriteria, yaitu: Sikap Kerja, Kecerdasan, Perilaku.

\section{REFERENCES}

[1] H. Purwanto, "Penerapan Metode Profile Matching Dalam Sistem Pendukung Keputusan Penilaian kinerja karyawan Pada PT .," vol. XIV, no. 1, pp. 15-20, 2017.

[2] "Elisabet Tunaeti anggraeni dan Rita Irviani, Pengantar Sistem Informasi, Yogyakarta: Penerbit Andi. 2017".

[3] M. K. Kusrini, Konsed dan Aplikasi Sistem Pendukung Keputusan. Yogyakarta: Penerbit Andi, 2007.

[4] "Jimmy Joses Sembiring, SH, M.Hum. SMART HRD Perusahaan tenang karyawan senang. Jakarta Selatan: KDT 2010"

[5] "Dr. Mohamad Ikbal Bahua, S.P., M.Si. Kinerja Penyuluh Pertanian, Yogyakarta: Penerbit DEEPUBLISH (Grup Penerbitan CV BUDI UTAMA). 2016."

[6] Abdul Kadir, Pengenalan Komputer, Yogyakarta: CV. Andi. 2013

[7] "Nugroho Adi "Rekayasa perangkat lunak menggunakan UML dan Java". penerbit Andi, Yogyakarta, 2009)" .

[8] Edy Winarno ST, M.Eng, Ali Zaki. Visual Basic. NET. Penerbit PT Elex Media Komputindo, Jakarta, 2013.

[9] "Dr. Said Mirza Pahlevi, Tujuh Langkah Praktis Pembangunan Basis Data, Jakarta: Penerbit PT. Alex Media Komputido,Jakarta. 2013" . 